\title{
Agents of Media Innovations:
}

\section{Actors, Actants, and Audiences}

\author{
Oscar Westlund \\ Department of Journalism, Media and Communication, University of Gothenburg \\ oscar.westlund@jmg.gu.se \\ www.oscarwestlund.com \\ Seth C. Lewis \\ School of Journalism \& Mass Communication, University of Minnesota-Twin Cities \\ sclewis@umn.edu \\ www.sethlewis.org
}

\begin{abstract}
In the contemporary media environment, media managers have been forced to reassess everything from editorial workflows to business models to technological platforms. Amid such challenges, legacy news media organizations are encouraged to innovate. Contemporary scholarly literature on media innovation typically adopts a relatively narrow approach when defining and studying the agents involved in shaping media innovations. Ultimately, many studies focus on individual parts of the organization rather than the complete system. There is thus a need to theorize and conceptualize the agents of media innovations in order to understand and improve activities of media innovations. This article presents the AMI approach (Agents of Media Innovations) as a holistic theoretical construct for understanding the agents of media innovation activities. We conceptualize this approach through a systematic discussion of four interlinked factors: actors, actants, audiences, and activities. These are used to compose and outline what we call the 4A Matrix, encompassing seven distinct and typological ways in which actors, actants, and audiences might intersect in the activities of media innovation. In mapping this interplay, the 4A Matrix serves as a heuristic for the scholarly study of media innovations, as well as a conceptual tool for envisioning, at a practical level, how media managers might act strategically.
\end{abstract}

The Journal of Media Innovations 1.2 (2014): 10-35

(C) Oscar Westlund and Seth Lewis 2014

http://www.journals.uio.no/index.php/TJMI 


\section{Introduction}

This article conceptualizes the agents involved in media innovation activitiesactors, actants, and audiences-focusing specifically on the salient case of innovation among news media companies. Journalism, as a profession, faces challenges to its occupational exclusivity (Lewis, 2012), and the news business in general faces challenges to its economic sustainability amid diminishing revenues from advertisers and audiences (Picard, 2014). Both such difficulties are well documented at this point. From the fragmenting of audiences to the shrinking of advertising revenue to the shifting dynamics of media production, distribution, and reception in a DIY environment of social, mobile, and personalized mediain all, it is a challenging mediascape for media companies in general and news organizations in particular (see, e.g., Anderson, Bell, \& Shirky, 2012). Quite a number of academic studies, media managers, and industry practitioners speak of the need for legacy news media organizations to engage more actively in organizational change and media innovation (Lewis \& Usher, 2013; Pavlik, 2013; Robinson, 2011; Ryfe, 2012; Schmitz Weiss \& Domingo, 2010). The journalism field is undergoing a substantial transition, characterized by some as a simultaneous twilight and dawn. This raises fundamental questions about the organizational and institutional arrangements through which journalism may be exercised and transformed (Picard, 2014). So-called "multi-platform content distribution" (Albarran, 2010) and "cross-media news work" (Westlund, 2011) have become increasingly common and important.

Legacy news media organizations are pressured to move beyond performing routinized media production of new content, which some scholars treat as innovation (see discussion in Dogruel, 2014) but which in this article is dismissed as true media innovation, insofar as innovation must involve something more than the repetitive cycle of everyday news production. In effect, legacy news media organizations need to act strategically and radically in improving their editorial processes and products as well as their business models and organizational structures. Case studies with newspapers from different countries have revealed organizational efforts toward such media innovation (Krumsvik, 2009; Raviola, 2010; Westlund, 2011). Nevertheless, both legacy news media organizations specifically (Picard \& Westlund, 2012) and the media and content industries generally have engaged relatively little in innovation (Bleyen et al., 2014), even as the creative industries more broadly appear to engage more in innovation, as indicated by an Austrian study (Müller et al., 2009). The aforementioned discussion sums up the first point of departure for this article: legacy news media organizations are pressured to and seemingly must innovate. Next we turn to the second point of departure for this article, identifying and addressing voids in literature and theory on media innovations.

Strategic management research typically seeks to understand why specific (media) firms outperform their peers (Mierzejewska, 2011). Several scholars of 
communication and media management have pointed to theoretical shortcomings with regard to how the media field has approached innovation (see reviews in Mierzejewska \& Hollifield, 2006; Sylvie \& Schmitz Weiss, 2012; Wirth, 2006), including the field of media innovations more specifically (see reviews in Bleyen et al., 2014; Dogruel, 2014; Storsul \& Krumsvik, 2013). Microeconomics research in media economics has produced many studies focusing on specific aspects of media firms, and their markets and consumers (Albarran, 2010). Some literature directly acknowledges the role of the organization for media innovation (Baumann, 2013; Bleyen et al., 2014), and how the media industries relate to organizational factors such as identity and reputation (Schweizer, 2003) as well as culture (Küng-Shankleman, 2000; cf. Mierzejewska, 2011). While these studies provide insight into the nexus of organizations and media innovation, they do not, however, provide a holistic perspective. There is a relative lack of studies in media management that incorporate sociotechnical perspectives (Sylvie \& Schmitz Weiss, 2012). A sociotechnical perspective involves studying and analyzing the roles played by human (social) actors and audiences as well as those played by technology and its diverse actants (Lewis \& Westlund, 2015a). By applying such sociotechnical and holistic perspectives, researchers may yield better answers to the relative performance of distinct media firms.

Most research seems to focus on the processes and products of media innovation rather than the organizational agents involved in shaping such innovation. Organizational approaches can indeed be found in literature deriving from related research fields, such as Industrial Organization (IO) and decisionmaking theory, as well as research on dynamic capabilities and the ResourceBased View (RBV). These approaches have previously been applied to research on innovation and strategy in the case of news publishers (see discussion in Fredberg, 2003; cf. Valanto et al., 2012) as well as other types of media firms (Mierzejewska, 2011). We find the RBV particularly relevant in this context, as it gives emphasis to how firms encompass and manage specific resources that facilitate their business operations and competitive advantage. These include the competencies (Prahalad \& Hamel, 1990) and skills (Grant, 1991) of their (human) staff, for example, how news publishers relate to technology and their audiences (Valanto et al., 2012). In the salient case of information systems, researchers have argued that a resource-based view should include more technologically specific resources, what Wade and Hulland (2004) discuss in terms of tangible assets such as hardware or network infrastructure, or intangible assets such as software patents. This points to the need for taking a more holistic approach, one incorporating human actors and technological actants more thoroughly, to study how organizations turn to media innovation.

To our best knowledge, contemporary literature at the nexus of organizational change and media innovation nevertheless appears to adopt a relatively narrow approach when defining and studying those agents participating in media innovation activities. This seems prevalent in the salient case of legacy news 
media organizations. Many studies examine media innovation only from the perspective of specific media managers-either businesspeople or editorial chiefs - thus focusing on individual parts of the organization rather than the complete system. In addition, few studies have explicitly integrated the seemingly active and influential roles for media innovation that are played by audiences and technologies as such. In sum, the second point of departure for this article: a need to theorize and conceptualize the agents of media innovations in order to understand and improve activities of media innovations.

On the basis of these two points of departures, this article attempts to develop a theoretical construct of the agents involved in activities of media innovations, with an emphasis on innovation at the level of the news media organization. This attempt toward a more holistic approach aims to guide how scholars might study and comprehend media innovation beyond the lens of one group of actors, and also how media managers and workers might approach media innovation in their practice. The article draws upon a series of conceptual factors called the Four A's - actors, actants, audiences, and activities - that are interlinked in configurations that transcend traditional notions of production and consumption, professional and nonprofessional, and intra- and extra-organizational (Lewis \& Westlund, 2015a). Actors refer to humans working within media organizations (e.g., journalists, technologists, and businesspeople), though it may also include social actors wielding influence from beyond the organization (e.g., citizens contributing to news production). Actants includes all nonhuman technologies such as algorithms, applications, networks, interfaces, content management systems, and other material objects that are enrolled in media work, whether programmed to work from inside, outside or across organizational boundaries. Audiences refers to the publics - of different kinds, represented on different platforms, assembled via different techniques - who are situated on the receiving end of media production and distribution, but who also contribute to media work by virtue of the data created about their engagement with content. The full range of dynamics among actors, actants, and audiences are interconnected through the activities of news organizations: from day-to-day processes to high-level strategies that define an organization's raison d'être (Lewis \& Westlund, 2015a).

The purpose of this article is to conceptualize and develop a holistic analytical framework for studying the agents of media innovations activities. For the sake of simplicity, our analytical framework will hereafter be referred to as the $A M I$ approach (Agents of Media Innovations). Our conceptualization will include three interrelated steps, each giving emphasis to discussing those involved in different sorts of media innovation activities: (1) briefly review the field of media innovation, emphasizing how it has considered (or not) the various agents involved in innovation processes; then, as a response to the first step, (2) conceptualize the general roles played by actors, actants and audiences in media innovation, which in turn leads to developing an analytical framework-(3) outlining the $4 A$ matrix, encompassing seven distinct and typological ways in 
which actors, actants, and audiences might intersect in activities of media innovation. Ultimately, the AMI approach forms a holistic and general analytical framework for understanding the dynamic roles played by agents of media innovations, while the seven distinct typologies outlined in the 4A Matrix constitute our primary contribution to the field of media innovations. The 4A Matrix serves as a heuristic for the scholarly study of media innovations, as well as a conceptual tool for envisioning, at a practical level, how media managers might navigate the challenges and opportunities associated with a changing media environment. The next sections discuss and conceptualize each of these three steps. A concluding discussion closes the article.

\section{Agents of media innovation at the organizational level}

Innovation, as a general concept, suggests creativeness and success in a competitive environment, and is popularly held as a holy grail, something for which to strive and claim as a source of pride. At the same time, some contend that innovation is not always the solution (Seelos \& Mair, 2012). The term derives from the Latin innovare and translates as "to change." In the business and organizational sense, innovation originally was defined as the (re)combination of distinct parts to form something new (Schumpeter, 1934/1997). As scholars have sought to make sense of innovation, they first identified it as the creative process of introducing ideas and change, and later suggested that an idea, invention or concept must be brought into use for it to count as an innovation (Cumming, 1998). Historically, structural approaches to studying organizations have emphasized their institutional stability, with innovation being a detour from normal conditions (Lewin, 1951). More recently, however, several fields of knowledge have developed a view that sees organizations as being continuously engaged in various sorts of innovation and change processes (Weick \& Quinn, 1999). Indeed, Stark (2009) has combined insights from economics and sociology to theorize that organizational innovation develops best not under conditions of shared understanding and seamless coordination — thus, stability — but rather amid the generative friction of discordance, ambiguity, and competing notions of value within firms. Innovation, in this sense, is connected to an organizational state of flux that Neff and Stark (2004) call "permanently beta," where fluidity can be associated with organizational improvement.

Even while signaling a certain degree of change, however, "innovation" includes an array of definitions, even within the single domain of business enterprise. In some cases it is perceived as a process of change, in other cases defined as the product of various change efforts. Storsul and Krumsvik (2013) posit that invention takes place when developing something, while innovation regards the implementation process. There are new or radical innovations as well as adaptive or incremental innovations, in addition to pure imitations (Tidd \& 
Bessant, 2013). Others discuss the development of innovations in products, markets, processes, and structures (Moore, 2005), and similarly, product, process, position and paradigmatic innovation (Francis \& Bessant, 2005). Many subscribe to the notion that disruptive innovation is desirable (Christensen, 1997), acting as the catalyst for new products, if not the creation of entirely new markets. Ultimately there is a positive rhetoric surrounding innovation, especially when it comes to disruptive innovation.

Bringing communication into this picture, media innovation refers to change not only in media technologies but also in media practices-i.e., practices carried out by media professionals as well as practices associated with user innovations (Bruns, 2014). Moreover, as Bruns argues, because media and society are becoming increasingly interlinked, making "media" the provenance of organizations and users alike via networked, interdependent systems of exchange, media innovation can be understood as a form of societal innovation-both a driver and a reflection of social change. Bruns, however, begins with "innovations in the media, by the media" (p. 14), and so do we-taking the vantage point of media organizations, and legacy news providers in particular, as the starting point for discussion. What is clear from such literature is the ongoing need for organizational adaptation to address parallel changes in media and society, involving a variety of technological as well as social, cultural, economic, and structural dynamics. Organizations, in effect, must learn to innovate (Picard $\&$ Westlund, 2012). In relation to innovation, research on organizational change stresses that adaptation and learning are central to how managers improve their effectiveness (Gavetti \& Levinthal, 2000; Miles \& Snow, 2003; Snow, Miles \& Miles, 2005), helping them improve their activities by developing dynamic capabilities (Zollo \& Winter, 2002) as well as using their diverse resources, such as skills (Grant, 1991), competencies (Prahalad \& Hamel, 1990), and assets (Wade \& Hulland, 2004). Importantly, there are different sorts of occupational subcultures within media organizations (Mierzejewska, 2011), each manifesting diverse resources. Moreover, scholars of media economics and media management argue that legacy news media organizations need to adapt (Picard, 2004; Picard, 2010; Krumsvik, 2009). This relates to how companies engage in different forms of organizational learning (Argyris 1977; Levitt \& March, 1988), such as the need for legacy news media companies to attend to vicarious, experiential, customer-based and structured environmental learning (Picard \&Westlund, 2012).

Against that backdrop, a critical question emerges: who (or what) is involved in the activities of media innovation and its processes of learning? Does the media firm take an organizational approach-involving different agents within and beyond the organization - or are only fragments of their diversified expertise participating and being studied? Next we turn our attention to the case of journalism and its media innovations. Much of this literature has emphasized human-centric considerations such as organizational constraints and socio- 
cultural factors that give shape to news production and content. We will briefly review and discuss the literature, attempting to trace the role (and absence) of different agents.

Research on news organizations typically has focused on editorial dimensions and newsroom dynamics (Domingo \& Paterson, 2011; Mitchelstein \& Boczkowski, 2009; Steensen, 2011), or such research has emphasized the business side and business models (e.g., Krumsvik, 2009; Raviola, 2010; Underwood, 1993). From their extensive research review of mass communication journals, Sylvie and Schmitz Weiss (2012) concluded that most of the studies focus on technology rather than management, and on specific journalistic skills rather than organizational/managerial themes. Moreover, we find that comparatively few studies have considered inter-departmental collaborations and influences (see, e.g., Gade, 2008; Doyle, 2014; Sylvie, 1996). What has gone missing, for the most part, is a focus on information technology specialists, such as computer programmers, coders, and other technicians whose work is increasingly salient not only for the servicing of technological infrastructure but also for the development of new types of news products-applications, algorithms, data visualizations, interactive databases, and the like (Lewis \& Usher, 2013; Parasie \& Dagiral, 2013; Royal, 2012). Moreover, few studies have empirically examined innovation processes among the full range of journalistic, business, and technological actors in news media organizations (exceptions include Nielsen, 2012; Westlund, 2011; 2012). The bottom line is that a more comprehensive account of human-centric considerations - among actors across departments and disciplines in the organization-reasonably offers a better approach to understanding how news media organizations innovate, and why they succeed or fail in doing so.

Additionally, to our best knowledge, scholars have paid little attention to the distinct and integral role that technological actants have to play in the overall unfolding of journalism innovation (Ananny, 2013; Aitamurto \& Lewis, 2013). Editorial content management systems (CMS) and technological architectures for managing big data - such as web analytics engines, algorithms, application programming interfaces (APIs), and so on-exemplify such socio-technical objects, inscribed with affordances that enable these actants to function as important nodes in contemporary innovation processes (Anderson \& Kreiss, 2013). We argue that scholars and media managers should be more attentive to the various roles that technological actants play now, and might play in the future, for media innovation.

Lastly, media firms carry out innovation in ways relating to their customers, partners, advertisers, readers, viewers, listeners, and users. Media firms, including legacy news media organizations, have developed increasingly prolific systems for and methods of tracking media consumption, which involves analyzing usage patterns across news media platforms. These analyses may be used for routinized editorial and business decisions, as well as for media 
innovation activities. Firms in different industries have long studied and innovated based on their analysis of so-called "lead users" who are familiar to emerging products and services (von Hippel, 1986). Moving beyond merely tracking and quantifying their audience, media firms likewise may seek to involve their audiences in innovation processes (von Hippel, 2005). Many contemporary firms in the creative industries partner with their audiences in different innovation processes (Müller et al., 2009). Indeed, in his conceptual article on media innovation, Bruns (2014) argues that media innovations in most cases are closely linked to user innovations, as evident in the development of specific features for the Twitter platform. His produsage concept, merging producers and users, is clearly applicable in this context (Bruns, 2012). More broadly, the field of innovation research recently has given rise to a number of concepts emphasizing the role of users as active members in innovation processes: distributed innovation, open innovation, and user innovation, to name a few (cf. Gassmann, Enkel \& Chesbrough, 2010). The active audience, we argue, must be conceptually integrated as a potentially important dimension when attempting to comprehend and study media innovation.

To sum up, this section has discussed the transforming meaning of the innovation concept, shed light on the importance of innovation (adaptation and organizational learning) for news media, and also argued that organizations need to embrace the full heterogeneity of their diverse resources. A discussion thereafter focused on research literature involving three agents, revealing the importance of social actors, technological actants, and audiences. Next follows a conceptualization of these agents for the salient case of media innovations.

\section{Conceptualizing the Agents of Media Innovations (the AMI approach)}

A holistic perspective of organizational media innovation in the salient case of news media requires a wider lens that encompasses the range of actors (e.g., editorial, business, and technology) involved in shaping news systems and strategies, and their interplay with actants and audiences. The AMI approach opens up opportunities for better identifying and actualizing media innovation and cross-media activities that involve the full range of possible combinations among actors, actants, and audiences. The conceptualization of the Four A'sactors, actants, and audiences engaging in activities-outlines the agents possibly involved, without predetermining their respective power and influence for a specific activity, as such may vary from case to case and also over time (Lewis \& Westlund, 2015a). The Four A's translate into four prerequisites for developing holistic representations of the AMI approach:

(1) Actors - studying the perceptions and behaviors of, and communication and cooperation among, all of the organizational actors potentially involved in innovation, across editorial, technological, and business elements alike; 
(2) Actants - acknowledging and analyzing how technological actants offer both enabling and disabling affordances in the salient case of innovation;

(3) Audiences - analyzing the variety of relationships that might exist between actors and audiences, mediated by different types of actants; and

(4) Activities - analyzing both proactive and reactive strategies toward innovation, across editorial, business, and technology concerns within the firm, and potential participants beyond the firm (e.g., consultancies, partners, etc.).

Hereafter follows a brief explication and conceptualization of actors, actants, and audiences as potential participants in media innovation. Each section forms a systematic discussion of extant literature, aimed to further conceptualize each of these A's as part of the proposed AMI approach. Following the conceptualization of the three A's, we turn to the proposed analytical framework, involving seven typologies of how these elements interplay in media innovation activities. Importantly, these seven typologies are constructed on the basis of power differentials among these agents. Much research has supposed-even taken for granted - that social actors within legacy news media organizations are in charge. In literature and practice, audiences have been designated a less influential role, no matter if they have been portrayed as recipients or active participants. If researchers have accounted for technological actants at all, these most likely have not been seen as independent, since they are man-made and managed by human social actors - unless approached from the perspective of actor-network theory in which power and agency is not determined a priori (Lewis \& Westlund, 2014; cf. Latour, 2005). One might approach this in terms of the classical principal-agent problem, which points to an asymmetrical relation: between the "agent" having the information and power to influence a "principal" in the direction of his or her interests (Rees, 1985a, 1985b). While acknowledging that human social actors wield much influence, important arguments in this article involve unpacking the possible importance and influence exerted by technological actants and audiences. Next we discuss each of these three agents in closer detail in the particular case of media innovations.

\section{Actors}

Looking internally, three social groups are most relevant to the news media organization: journalists, technologists, and businesspeople. The first group has received much of the attention in the journalism studies and media sociology literatures (discussed, for instance, in Zelizer, 2004); this is particularly true of late with regard to the relationship that journalists have with technology (e.g., Boczkowski, 2004; Domingo \& Paterson, 2011; Gynnild, 2014; Mitchelstein \& Boczkowski, 2009; Lewis, 2012; Robinson, 2011; Steensen, 2011). While journalists have long worked with machines (technology) and machine-operators (technicians) to accomplish journalism, what is striking about the contemporary 
environment is the extent to which media production has transitioned from "dumb" tools requiring a high degree of human direction to increasingly "smart" technologies that help automate or algorithmically augment various processes of journalism without any human action. In some cases, machines literally replace journalists altogether, as in machine-written forms of "robot journalism" (van Dalen, 2012). This ongoing development raises questions about how editorial workers are negotiating issues of authority, identity, and expertise in connection with emerging forms of newswork that are intimately connected to digital media (Powers, 2012), such as news aggregation. It also suggests that attention need be given to the role of machine-led processes in performing journalistic functions (Bakker, 2012; Westlund, 2013).

The second group of social actors, technologists, includes an array of information technology (IT) specialists with a variety of titles: programmers, web developers, data scientists, database managers, project managers, systems designers, and so on. Some IT specialists work on editorial products, others focus on business services, and some combination of the two straddle departments, supporting the systems of digital production and distribution. While scholars have begun to give greater attention to the emerging role of technologists in the newsroom (Parasie \& Dagiral, 2013) and in the journalism field broadly (Gynnild, 2014; Lewis \& Usher, 2013), comparatively less attention has been paid to the work of technologists for business ventures or across departments (Westlund, 2011).

The third group of actors includes all those associated with supporting the business side of the cross-media enterprise: marketers, sales associates, customer relationship managers, etc. Observers such as Underwood (1993) have attempted to deconstruct how "MBAs rule the newsroom," or how customer-driven, profitcentric priorities have come to threaten professional news values and ethics in corporatized media environments (Hamilton, 2004) — but relatively few studies have sought to understand the business side of a news organization as it relates to technological adoption and innovation in journalism. Moreover, while journalism studies has emphasized journalistic norms and values (e.g., Domingo \& Paterson, 2011) and the media economics and management literature has focused on commercial managers and matters (Küng, 2008), technologists, by contrast, have been mostly "black-boxed" (Latour, 1987) - forgotten as key objects of study because they are situated so thoroughly in the background.

A more holistic approach to studying media innovations and/or cross-media news work would examine the social construction of technology at the intersection of editorial, business, and technology, as Nielsen (2012) did in studying newspaper blogging platforms and Westlund $(2011,2012)$ did in his analyses of mobile news development. Going forward, such a perspective might help researchers better assess growing forms of coordination between the editorial and business sides, through the collaborative development of information products and services for multiple platforms. For example, to what 
extent are new combinations of market principles - the business logic (Hamilton, 2004) - and technologist-driven cultures, norms, and practices - the technology logic (Lewis \& Usher, 2013) — working to shape the editorial logic of news organizations and its subsequent incorporation of native advertising, branded content, and related experiments in business, technology, and news?

\section{Actants}

The term actants, as we use it here, may refer to material objects that are notable for their association with human actors and the activities they undertake in conjunction with such objects. Actor-network theory (ANT), a sociological and methodological approach concerned with tracing associations ("following the actors to where they lead the researcher," in the common refrain), is the framework most frequently invoked to describe the nature of actants in journalism and media studies (Plesner, 2009). ANT does not erase distinctions between human and nonhuman, but neither does it privilege one over the other in assessing the relative "force" through which the social or the technological determines outcomes. As Latour (2005, p. 71) notes, "the questions to ask about any agent are simply the following: Does it make a difference in the course of some agent's action or not?" Thus, in this discussion of cross-media news work, the question would become: Does a technological object like a content management system (CMS), application programming interface (API), or set of software code make a difference in the course of some actors' activities or not? While this article cannot undertake a thorough review of ANT and journalism (for that, see Hemmingway, 2008; Plesner, 2009), we simply take as a starting point that actants are socially constructed to suit journalistic, commercial, and technological purposes within news organizations. Technological actants may be developed and reconfigured by actors placed both internal and external to the news media organization. It is in this social framing process, for instance, that CMS technology are encoded with news values, shaping how particular types of content are chosen for publication across particular platforms.

Even amid a long line of research documenting how legacy news media organizations work with the technological affordances of digital media, relatively few studies have clarified exactly why some technological assets are incorporated and others are not (Steensen, 2011). This leaves open certain questions about the nature of the actants themselves. Answering Latour's "does it make a difference?" question becomes challenging when the literature has neither thoroughly identified the "it" (actant) in question nor the full array of contextual influences connected with its supposed difference-making. Applying this need to the study of media innovation in news organizations, a research approach that puts actants first - or at least on par with actors-may help to clarify the particular role of technologies in structuring cross-media news work, by virtue of 
their affordances and networked interactions with other actors, actants, and audiences. This can be done either with an internal gaze (e.g., Plesner's [2009] study of email's intra-newsroom role) or an external one (e.g., Ananny's [2013] study of news APIs that are situated betwixt news organizations and outside technologists). Both internal and external perspectives provide actant-level context that reveals a more holistic understanding of the distinct role of technological agents and their implications.

\section{Audiences}

In the contemporary media landscape, audiences may seem like a contested term. While the shift from mass communication to what Castells (2007) calls "mass self-communication" certainly challenges traditional distinctions between producers and consumers, this does not mark the "end of the audience" so much as an evolution in how audiences are understood by media institutions. As Napoli (2010) argues, in the present "post-exposure audience marketplace," older metrics of audience exposure (e.g., viewership, readership, etc.) are being replaced by more detailed determinations of audience perceptions and practices (e.g., likes, shares, time-on-site, and so on), made possible by a massive degree of consumer tracking across websites, apps, location coordinates, and more. This shifting focus on audience engagement is a rationalization of the data gathered and analyzed via audience information systems like Chartbeat and Google Analytics, but it also reflects an interest in understanding audiences' increased autonomy and creative potential in digital spaces - a sense that audiences, while increasingly tracked, may be useful for what they can contribute to the media ecosystem, not merely for how they consume content within it. Thus, a dual view of the audience emerges: as commodities for media advertisers, on the one hand, and as active media participants in cultural production, on the other. Within the media organization, business managers may take a commodity view even while also recognizing the audience's utility in making media content viral and "spreadable" (Jenkins, Ford, \& Green, 2013; cf. Jennes, Pierson \& Van den Broeck, 2014). Journalists, meanwhile, may see audiences as participants even as they struggle to deal with such participation because it challenges their professional control (Lewis, 2012). This professional control also is challenged by both new and established companies that are developing applications that process and publish stories and data (Bierhoff \& Kruitwagen, 2014; Lewis \& Westlund, 2015b).

Both the audiences-as-commodities (Smythe, 1977; Turow, 2005) and audiences-as-participants (Jenkins, 2006) perspectives have long histories in mass communication research. While a full treatment of such literature is not possible here (for discussion, see Bolin, 2012), what is notable in the context of the AMI approach described here is that how media firms conceptualize the audience is 
connected with how they learn and innovate, as Picard and Westlund (2012) have argued. Newspapers, they note, have traditionally taken a producer-centric approach, meaning that their actors predominantly relied on professional values for judgments, hardly bothering to understand their audience at all (see also Boczkowski \& Mitchelstein, 2013). However, news media have since developed a consumer-centric approach, thereby treating the audience as a commodity to be served and sold. Actors in news media organizations have increasingly mobilized resources, like the audience information systems described by Napoli (2010), to facilitate greater measurement, analysis, and commercialization of digital audiences. And even journalists are becoming increasingly aware of, if not necessarily beholden to, audience clicks (see discussion in Lee, Lewis, \& Powers, 2014). At the same time, news organizations are becoming more aware of audiences as productive participants, particularly through social media channels that afford easy journalist-audience interaction around breaking news events (Hermida, 2013). Against resistance, news organizations in some cases have taken a participation-centric approach, through which their actors try to involve their audiences in activities of journalism as well as business innovation (Picard \& Westlund, 2012). Relatively little research, however, has explored the implications of changing perceptions about audiences for media management and media work in a holistic sense, involving journalists, technologists, and businesspeople - not to mention actors and actants in the widest sense as well.

\section{The activities of organizational media innovation: Outlining the 4A Matrix}

Media activities generally can be seen as routinized practices geared toward shaping diverse forms of media messages as well as their subsequent circulation and reception (Couldry, 2012). Relating to media organizations more specifically, media activities are patterns of action through which an organization operationalizes and manifests its different institutional logics and strategic ambitions. Moreover, activities of media innovation also include emerging and sporadic efforts, relating both to the invention and implementation of an innovation.

There are a number of different ways in which actors, actants, and audiences might intersect in media innovation activities. The influence exerted by actors, actants, and audiences may vary with the invention and implementation of specific innovations. For instance, social actors may be important in generating creative ideas for the invention phase, and also for the strategies, tactics, and media work of the implementation phase. Nevertheless, actants such as information systems for business intelligence and big data may play a crucial role in collecting and structuring data that reveals ideas for invention, and these as well as other actants may be important for implementing the innovation. Moreover, audiences may be invited to participate directly in idea generation 
Table 1: The 4A Matrix: Actors, Actants, and Audiences in Media Innovation Activities. The table illustrates seven typologies for strategic directions in media innovation activities based on plausible combinations of three distinct agents: actors, actants, and audiences. That is, there are seven distinct ways in which these three agents might interrelate in activities of media innovation

\begin{tabular}{lccc} 
Approach & Actors & Actants & Audiences \\
\hline Actor-led & $\mathrm{X}$ & & \\
Actant-led & & $\mathrm{X}$ & \\
Audience-led & & & $\mathrm{X}$ \\
Actor/Actant-led & $\mathrm{X}$ & $\mathrm{X}$ & \\
Actor/Audience-led & $\mathrm{X}$ & & $\mathrm{X}$ \\
Actant/Audience-led & & $\mathrm{X}$ & $\mathrm{X}$ \\
3A & $\mathrm{X}$ & $\mathrm{X}$ & $\mathrm{X}$
\end{tabular}

through focus groups, panel studies, and so forth—or more indirectly by having their digital news consumption traced, aggregated, and analyzed. Audiences (or other external actors) also may play a role in the implementation phase-for instance, by contributing to the development of an open-source project if the media company adopts more transparent processes of technology development (cf. Aitamurto \& Lewis, 2013). Research has also shown how diverse social actors negotiate the ways in which actants are to carry out some of their work through automation, as well as how actors inscribe actants with the affordances facilitating the ways that audiences might engage with their products and services (Westlund, 2012). The more specific literature on innovation and media work in news media organizations points to matters of power and influence between different agents in media firms, which may be manifest in tensions between intraorganizational human actors, between humans and actants, and between producers and their audiences (Lewis \& Westlund, 2015a; cf. Westlund, 2011).

On the basis of the AMI approach, and more specifically the distribution of power among actors, actants, and audiences in shaping media innovation processes, we introduce a mapping that outlines different ways that agents might get involved (see Table 1). We have distinguished seven salient approaches from a study of the general ways that actors, actants, and audiences might intersect. The 4A Matrix delineates these diverse approaches, focusing on media innovation in the particular context of news media. Firstly, we introduce three approaches in which only one agent dominates the approach to media innovations; thereafter follows three approaches in which two agents jointly have dominance; finally, there is one approach in which all three agents have equal significance in various activities.

Take care to notice that although "actors" are referred to as one in the matrix, empirical studies of organizational innovation should attempt to study and analyze the diverse roles and influences that different actors may have, 
distinguishing journalists, businesspeople, and technologists. Moreover, actants may be developed and situated both within and beyond the media firm, and audiences may be conceptualized and approached in several distinct ways (Lewis $\&$ Westlund, 2015a). Also take care to notice that the seven approaches are introduced in a general fashion, and thus may be applied to various sorts of contemporary sites of media innovation, including but not limited to mobile media, live-blogging, big data, computational journalism, and locative media.

\section{The Actor-led Approach}

This approach involves strong position-taking by human actors, while technological actants and audiences have a weaker position. Obviously, this is the cognitive perspective typically adopted by scholars and practitioners alike. It also constitutes the paradigm of twentieth-century mass media: a heavy emphasis on human gatekeeping of news stories and business strategy. Indeed, technological innovation did not have an impact in many newsrooms until the 1970s (Picard \& Brody, 1997). Still today, journalists exert much influence in both determining their work routines and guiding media innovations, though businesspeople and technologists increasingly have significance in shaping how distinct innovations are created and put into use (Nielsen, 2012; Westlund, 2011). This is especially true as the "wall" separating editorial and business domains, in many cases, becomes more porous as economic considerations assume greater priority (Coddington, 2015). Moreover, while research generally has held that the journalists are most influential, recent scholarship suggests the growing significance of technologists, whose programming skill sets are particularly prized by news media organizations seeking to develop interactive news

applications and related computational approaches (Parasie \& Dagiral, 2013; Hamilton \& Turner, 2009; Lewis \& Usher, 2013). Thus, scholars and practitioners must acknowledge the full range of experts, cultures, and practices among journalists, technologists, and businesspeople. Technological actants and audiences, in this view, are granted limited influence.

\section{The Actant-led Approach}

Characterized by empowered technological actants, this approach involves human actors assuming a downplayed role, while audiences remain in their historically weak position. This is not to suggest that technologies in and of themselves have agency and power; they remain socially constructed and instructed. Indeed, even as technologies increasingly facilitate automation, they are not entirely autonomous (Stensson \& Jansson, 2014). Nevertheless, under certain conditions, news organizations might give to technology some activities, even leading 
priorities and core competencies, that previously belonged to humans. This can be seen in the algorithmic selection and sorting of news headlines and machinewritten news stories, as well as an increased reliance on data-backed applications to guide, even automate, decisions about which advertisements to target to particular types of audiences and individuals. Humans retain their role in encoding such tools, of course, but the logic of the organization becomes increasingly situated around letting (machine-learning) actants "do the work" when media innovations are implemented into more routinized media work such as journalism (cf. Ananny, 2013; Westlund, 2013). For instance, newspapers such as Sweden's Göteborgs-Posten use prolific editorial content management systems (CMS) and algorithms for implementing and running mobile news publishing (Westlund, 2011, 2012).

\section{The Audience-led Approach}

Here, the audience assumes a more forward position. While it is virtually impossible to imagine a news organization that yields ultimate authority to audiences - wither the organization's purpose in such a scenario?-we might begin to think of contexts in which the choices and contributions of audiences are especially powerful in shaping the media experience (cf. Bolin, 2012). The Demand Media style of journalism imagined by Anderson (2011) — in which content is crafted solely to suit audience interests, rather than producers' desires - can be seen in the likes of BuzzFeed, Business Insider, Huffington Post, and other sites that, by design, are in the service of audience tastes and make prominent how audiences have liked certain content. As active participants who like, share, and comment, audiences may play a role in both the invention and implementation of innovations; this is particularly true insofar as news media organizations make themselves open to audience input and involvement regarding the processes as well as the products of news - as The Guardian, notably, has attempted. Moreover, to the extent that news sites adopt the popular model of Reddit and other sites that encourage user contributions as the primary content and user activity as the key determinant of news placement, the audience-driven approach may emerge as a key strategy for media innovation (cf. Bakker, 2012).

\section{The Actor/Actant-led Approach}

This approach, the first of the hybrid variations we model, characterizes firms in which organizational actors and technological actants mutually shape and manage their routine media work as well as their media innovations. That is, neither actors nor actants push innovation more than one another, but do so in equal collaboration. Actors - whether journalists, technologists, or businesspeople- 
inscribe actants with the capabilities to perform certain work, such as news repurposing across platforms, and also program them to offer customized experiences using data derived from audience information systems. For example, the technology news site Techmeme relies on a combination of algorithms and human editors to determine the order and variety of links on its homepage. Additionally, journalists produce news content that may become innovative when put through specific "re-production technologies" (Schweizer, 2003), with the assistance of programming from technologists. One such innovation has been developed at The Los Angeles Times, which designed a robot to automatically gather and produce a preliminary report about earthquakes immediately after they happen - the text ready for subsequent manual editing and approval by a human journalist before publication online, within minutes of the event (Cruz, 2014).

\section{The Actor/Audience-led Approach}

In this scenario, the organization has reconfigured its relationship with its audience, creating dynamic forms of involvement that go beyond merely seeing audiences as "active recipients" (Hermida, 2011). This might include more reciprocal forms of exchange that are seen as mutually beneficial for organization and audience alike (Lewis, Holton, \& Coddington, 2014), or forms of produsage, wherein users are invited to act as producers of media content on more equal terms (Bruns, 2012). Media producers may approach their audiences as contributors to media innovations in diverse ways, taking a participation-centric approach that includes user-led innovation and different forms of networked and distributed innovation processes (Picard \& Westlund, 2012). Exemplifying the Actor/Audience-led approach, actors working for legacy news media organizations have taken various initiatives toward facilitating dialogue and involvement with their audiences, such as inviting them to their premises, talking to them at malls, and organizing public events focused on societal or cultural issues. Audiences have also become directly involved in discussing trends as well as product- and process-level innovation, testing prototypes before inventions are put into use.

\section{The Actant/Audience-led Approach}

Organizations taking this approach rely more heavily on technological actants and external actors to shape the substance of media activities - perhaps by giving algorithms and audiences a greater say in gatekeeping. For instance, Singer (2014) discusses user-generated visibility as a kind of secondary gatekeeping, affording an expanded role to users - and the social media applications and algorithms upon which they rely-in shaping the prominence of particular news 
items. The strategic rationale for the actant/audience-led approach may be purely economic: As legacy news media organizations face the need to downsize staff, they might delegate more autonomy to actants and audiences. In a limited but growing set of cases, news organizations are relying on technological actants to perform so-called "robot journalism"-producing news stories based on automatic evaluation of data, as in the case of Forbes.com relying on Narrative Science's software to auto-generate hundreds of stories about the quarterly earnings reports of publicly traded companies in the U.S.

\section{The 3 A Approach}

This final, combined approach refers to organizations in which actors, actants, and audiences, in a symbiotic arrangement, mutually shape media the invention and implementation of distinct media innovations. The $3 \mathrm{~A}$ approach signifies a possible path of development, considering the wider spectrum of situations and sites where actants and audiences demonstrate increasing significance. Supposedly few organizations would, of course, be found to reflect a truly "equal" approach in this way, given that certain factors of production (e.g., human vs. machine) and distribution (e.g., the relative strength of audience influence) are likely to hold more relevance than others depending on the strategic positioning of the firms in question. Nevertheless, this seventh perspective is useful in highlighting the questions raised by such a scenario: For example, what are the macro (economic) and micro (organizational) conditions under which each of these A's might more readily possess equal —or nearly equal-influence in the negotiation of media innovation activities within a given firm?

\section{Concluding discussion}

The scholarly study of media innovations is a complicated endeavor, and traditional theories and concepts can take scholars only so far with regard to the study of agents in media innovation. Thus, we have promoted the AMI approach to account for how human actors, technological actants, and audiences interplay in the activities of media innovation. This article has presented a systematic discussion of actors, actants, and audiences in the salient case of news media innovation, culminating in the 4A Matrix, which outlines a typology of seven possible approaches to media innovations.

The 4A Matrix forms an analytical framework that may guide scholars and managers in their future attempts to grasp and approach media innovations. There are many market opportunities and technical affordances through which media managers may develop their innovative capacity, such as mobile media, big data, 
locative media, and personalized services. These contexts may intersect as human actors in media firms develop and employ technological actants for process innovation, improving their approaches to capturing, mining, aggregating, and analyzing data on their audiences' locations and uses of mobile media. Such activities may provide audiences with greater value through personalization, offering technology-led customization of relevant content and services (cf. Westlund, 2013) - and simultaneously provide organizations with better data about audiences for greater revenue generation. In all, these activities may catalyze further media innovations, even as they also may raise troubling questions about individuals' data privacy (boyd \& Crawford, 2012) and other concerns at the intersection of ethics, epistemology, expertise, and economics (Lewis \& Westlund, 2015b). Ultimately, we argue that the AMI approach presented here offers much conceptual guidance, and the 4A Matrix offers much practical guidance.

Future research may draw upon the AMI approach to more thoroughly study, review, synthesize, and conceptualize different projects of media innovation as these unfold. We encourage studies that focus on the dynamic interplay of actors, actants, and audiences in activities of media innovation. Empirical research might explore the seven approaches outlined in the 4A Matrix, using its framework to study a variety of comparative contexts: the relative success of organizational innovations, the differences within and across firms and media systems, and the interplay of social, cultural, and technological factors with structural characteristics associated with media industries and geopolitical contexts. These, we hope, will lead to further conceptualization and reconfiguration of the $4 \mathrm{~A}$ Matrix for the study of media innovations. Ultimately, the 4A Matrix also may be used by media managers within a single firm as well as by media collectivessuch as the World Association of Newspapers (WAN-IFRA) in the news industry - in their continuous efforts to develop their media innovations.

\section{References}

Aitamurto, T., \& Lewis, S. C. (2013). Open innovation in digital journalism:

Examining the impact of open APIs at four news organizations. New Media \& Society, 15(2), 314-331. doi:10.1177/1461444812450682

Albarran, A. B. (2010). The media economy. London: Bridge.

Ananny, M. (2013). Press-Public collaboration as infrastructure: Tracing news organizations and programming publics in application programming interfaces. American Behavioral Scientist, 57(5), 623-642.

doi:10.1177/0002764212469363

Anderson, C. W. (2011). Deliberative, agonistic, and algorithmic audiences: Journalism's vision of its public in an age of audience transparency.

International Journal of Communication, 5(0), 529-547.

http://ijoc.org/index.php/ijoc/article/view/884 
Anderson, C. W., Bell, E \& Shirky, C. (2012). Post-industrial journalism: Adapting to the present. New York: Tow Center for Digital Journalism, Columbia University. Retrieved from http://towcenter.org/research/postindustrial-journalism/

Anderson, C. W., \& Kreiss, D. (2013). Black boxes as capacities for and constraints on action: Electoral politics, journalism, and devices of representation. Qualitative Sociology, 36(4), 365-382. doi:10.1007/s11133013-9258-4

Argyris, C. (1977). Double loop learning in organizations, Harvard Business Review, September-October 1977, 115-125.

Baumann, S. (2013). Adapting to the Brave New World: Innovative Organisational Strategies for Media Companies. In T. Storsul \& A.H. Krumsvik (eds.), Media Innovation: A Multidisciplinary Study of Change (pp. 77-92), Göteborg: Nordicom.

Bakker, P. (2012). Aggregation, content farms and Huffinization: The rise of lowpay and no-pay journalism. Journalism Practice, 6(5-6), 627-637. doi:10.1080/17512786.2012.667266

Bierhoff, J., \& Kruitwagen, S. (2014). Stories Behind the News; Designing an Advanced App for Journalistic Background Information. The Journal of Media Innovations, 1(1), 110-128. doi: 10.5617/jmi.v1i1.770

Bleyen, V., Lindmark, S., Ranaivoson, H., \& Ballon, P. (2014). A typology of media innovations: Insights from an exploratory study, The Journal of Media Innovations, 1(1), 28-51.

Boczkowski, P. J. (2004). Digitizing the news: Innovation in online newspapers. Cambridge, MA: MIT Press.

Boczkowski, P. J., \& Mitchelstein, E. (2013). The news gap: When the information preferences of the media and the public diverge. Cambridge, Massachusetts: The MIT Press.

Bolin, G. (2012). The labour of media use: The two active audiences. Information, Communication \& Society, 15(6), 796-814. doi:10.1080/1369118X.2012.677052

boyd, d., \& Crawford, K. (2012). Critical questions for big data: Provocations for a cultural, technological, and scholarly phenomenon. Information, Communication \& Society, 15(5), 662-679. doi:10.1080/1369118X.2012.678878

Bruns, A. (2012). Reconciling community and commerce? Collaboration between produsage communities and commercial operators, Information, Communication \& Society, 15(6), 815-835. doi:10.1080/1369118X.2012.680482

Bruns, A. (2014). Media innovations, user innovations, societal innovations, The Journal of Media Innovations, 1(1), 13-27. doi: 10.5617/jmi.v1i1.827

Castells, M. (2007). Communication, power and counter-power in the network society. International Journal of Communication, 1(1), 238-266. 
Christensen, C. M. (1997). The innovator's dilemma: When new technologies cause great firms to fail. Boston, MA: Harvard Business School Press.

Coddington, M. (2015). The wall becomes a curtain: Revisiting journalism's news-business boundary. In M. Carlson \& S. C. Lewis (Eds.), Boundaries of Journalism: Professionalism, Practices, and Participation. New York: Routledge. [forthcoming]

Couldry, N. (2012). Media, society, world: Social theory and digital media practice. Cambridge: Polity.

Cruz, D. (2014). Journalist uses algorithm to gather earthquake data and write reports in minutes (https://knightcenter.utexas.edu/blog/00-15305-journalistuses-algorithm-gather-earthquake-data-and-write-reports-minutes) (Published 2014-03-18).

Cumming, B. S. (1998). Innovation overview and future challenges. European Journal of Innovation Management, 1(1), 21-29.

Dogruel, L. (2014). What is so special about media innovations? A characterization of the field. The Journal of Media Innovations, 1(1), 28-51.

Domingo, D., \& Paterson, C. A. (Eds.) (2011). Making online news: Newsroom ethnographies in the second decade of internet journalism. New York: Peter Lang.

Doyle, G. (2014). Re-invention and survival: newspapers in the era of digital multiplatform delivery. Journal of Media Business Studies, 10 (4), 1-20.

Francis, D. \& Bessant, J. (2005). Targeting innovation and implications for capability development. Technovation, 25(3), 171-183.

Fredberg, T. (2003). Interface strategies - internet and the business of large Swedish daily newspapers, Department of Project Management, Chalmers University of Technology, Gothenburg.

Gade, P. J. (2008). Journalism Guardians in a Time of Great Change: Newspaper Editors' Perceived Influence in Integrated News Organizations. Journalism \& Mass Communication Quarterly, 85(2), 371-392.

Gavetti, G., \& Levinthal, D. E. (2000). Looking forward and looking backward: Cognitive and experiential search. Administrative Science Quarterly, 45(1), 113-137. doi: 10.2307/2666981

Gassmann, O., Enkel, E., \& Chesbrough, H. (2010). The future of open innovation, $R \& D$ Management, 40(3), 214-221.

Grant, R. M. (1991). The Resource-Based Theory of Competitive Advantage: Implications for Strategy Formulation. California Management Review, 33(1), 114-135.

Gynnild, A. (2014). Journalism innovation leads to innovation journalism: The impact of computational exploration on changing mindsets. Journalism, 15(6), 713-730. doi:10.1177/1464884913486393

Hamilton, J. T. (2004). All the news that's fit to sell: How the market transforms information into news. Princeton, N.J.: Princeton University Press. 
Hamilton, J. T., \& Turner, F. (2009). Accountability through algorithm: Developing the field of computational journalism. Report from the Center for Advanced Study in the Behavioral Sciences, Summer Workshop 27-41. Duke University: Durham, NC.

Hemmingway, E. (2008). Into the newsroom: Exploring the digital production of regional television news. London: Routledge.

Hermida, A. (2011). Fluid Spaces, Fluid Journalism: Lessons in Participatory Journalism. In J. B. Singer, D. Domingo, A. Heinonen, A. Hermida, S. Paulussen, T. Quandt, Z. Reich, \& M. Vujnovic (Eds.) Participatory Journalism: Guarding Open Gates at Online Newspapers (pp. 177-191), Malden, MA: Wiley-Blackwell.

Hermida, A. (2013). \#Journalism: Reconfiguring journalism research about twitter, one tweet at a time. Digital Journalism, 1(3), 295-313. doi:10.1080/21670811.2013.808456

Jenkins, H. (2006). Convergence culture: Where old and new media collide. New York: New York University Press.

Jenkins, H., Ford, S. \& Green, J. (2012). Spreadable Media: Creating Value and Meaning in a Networked Culture. New York: NYU Press.

Jennes, I., Pierson, J. \& Van den Broeck, W. (2014). User Empowerment and Audience Commodification in a Commercial Television Context. The Journal of Media Innovations, 1(1), 71-87. doi: 10.5617/jmi.v1i1.723

Krumsvik, A. H. (2009). The online news factory: a multi-lens investigation of the strategy, structure, and process of online news production at CNN and $N R K$. Doctoral dissertation, Oslo, University of Oslo/Unipub.

Küng, L. (2008). Strategic Management in the Media. London: Sage.

Küng-Shankleman, L. (2000). Inside the BBC and CNN: Managing Media Organisations. London: Routledge.

Latour, B. (1987). Science in action. Cambridge, MA: Harvard University Press.

Latour, B. (2005) Reassembling the Social: An Introduction to Actor-NetworkTheory. Oxford: Oxford University Press.

Lee, A. M., Lewis, S. C., \& Powers, M. (2014). Audience clicks and news placement: A study of time-lagged influence in online journalism. Communication Research, 41(4), 505-530. doi:10.1177/0093650212467031

Levitt, B., \& March, J. G. (1988). Organizational Learning. Annual Review of Sociology, 14, 319-338.

Lewin, K. (1951). Field Theory in Social Science: Selected Theoretical Papers. New York: Harper \& Brothers.

Lewis, S. C. (2012). The tension between professional control and open participation: Journalism and its boundaries. Information, Communication \& Society, 15(6), 836-866. doi:10.1080/1369118X.2012.674150

Lewis, S. C., Holton, A. E., \& Coddington, M. (2014). Reciprocal journalism: A concept of mutual exchange between journalists and audiences. Journalism Practice, 8(2), 229-241. doi:10.1080/17512786.2013.859840 
Lewis, S. C., \& Westlund, O. (2015a). Actors, Actants, Audiences, and Activities in Cross-Media News Work: A matrix and a research agenda. Digital Journalism, 3(1). doi: 10.1080/21670811.2014.927986

Lewis, S. C., \& Westlund, O. (2015b). Big data and journalism: Epistemology, expertise, economics, and ethics. Digital Journalism. [forthcoming]

Lewis, S. C., \& Usher, N. (2013). Open source and journalism: Toward new frameworks for imagining news innovation. Media, Culture \& Society, 35(5), 602-619. doi:10.1177/0163443713485494

Mierzejewska, B.I. (2011). Media Management in theory and practice. In M. Deuze (Ed.), Managing Media Work (pp. 13-30). Los Angeles: Sage.

Mierzejewska, B. I., \& Hollifield, A. C. (2006). Theoretical approaches in media management research. In A. B. Albarran., S. Chan-Olmsted \& M. O. Wirth (Eds.), Handbook of media management and economics (pp. 37-66), Mahwah, NJ: Lawrence Erlbaum Associates, Inc.

Miles, R. E. \& Snow, C. C. (2003). Organizational strategy, structure, and process: Stanford business classics. Stanford: Stanford University Press.

Mitchelstein, E. \& Boczkowski, P. J. (2009). Between tradition and change: A review of recent research on online news production. Journalism, 10(5), 562586.

Moore, G. A. (2005). Dealing with Darwin: How Great Companies Innovate at Every Phase of Their Evolution, New York: Portfolio.

Müller, K., Rammer, C. \& Trüby, J. (2009). The role of creative industries in industrial innovation. Innovation: Management, Policy \& Practice, 11(2), 148-168.

Napoli, P. M. (2010). Audience evolution: New technologies and the transformation of media audiences. New York: Columbia University Press.

Neff, G., \& Stark, D. (2004). "Permanently beta". In P.N. Howard \& S. Jones (Eds.), Society online: The internet in context (pp. 173-188). Thousand Oaks, CA: Sage.

Nielsen, R. K. (2012). How newspapers began to blog: Recognizing the role of technologists in old media organizations' development of new media technologies. Information, Communication \& Society, 15(6), 959-978. doi: 10.1080/1369118X.2012.694898

Parasie, S., \& Dagiral, E. (2013). Data-driven journalism and the public good: "Computer-assisted-reporters" and "programmer-journalists" in Chicago. New Media \& Society, 15(6), 853-871. doi:10.1080/1369118X.2012.694898

Pavlik, J. V. (2013). Trends in New Media Research: A Critical Review of Recent Scholarship. Sociology Compass, 7(1), 1-12. doi:10.1177/1461444812463345

Picard, R. G. (Ed.) (2004). Strategic Responses to Media Market Changes. Jönlöping, Sweden: Jönköping International Business School. 
Picard, R. G. (2010). Value Creation and the Future of News Organizations: Why and How Journalism Must Change to Remain Relevant in the Twenty-First Century. Lisbon: Media XX.

Picard, R. G. (2014). Twilight or New Dawn of Journalism? Journalism Studies. doi: 10.1080/1461670X.2014.895530

Picard, R. G., \& Brody, J.H. (1997). The newspaper publishing industry. Boston, MA: Allyn and Bacon.

Picard, R. G. \& Westlund, O. (2012). The Dynamic Innovation Learning Model: A Conceptualization of Media Innovation, Paper presented at the 10th World Media Economics and Management Conference, Thessaloniki, Greece, May 23-27, 2012.

Plesner, U. (2009). An actor-network perspective on changing work practices: Communication technologies as actants in newswork. Journalism, 10(5), 604626. doi:10.1177/1464884909106535

Prahalad, C. K., \& Hamel, G. (1990). The Core Competence of the Corporation. Harvard Business Review, 68 (3), 79-92.

Powers, M. (2012). In forms that are familiar and yet-to-be invented: American journalism and the discourse of technologically specific work. Journal of Communication Inquiry, 36(1), 24-43. doi:10.1177/0196859911426009

Raviola, E. (2010). Paper meets web - how the institution of news production works on paper and online. JIBS Dissertation Series No. 065, Jönköping International Business School, Jönköping, Sweden.

Rees, R. (1985a). The Theory of Principal and Agent-Part I. Bulletin of Economic Research, 37 (1), 3-26.

Rees, R. (1985b). The Theory of Principal and Agent-Part II. Bulletin of Economic Research, 37(2), 75-97.

Robinson, S. (2011). "Journalism as process": The organizational implications of participatory content in news organization. Journalism \& Communication Monographs, 13(3), 138-210. doi:10.1177/152263791101300302

Royal, C. (2012). The Journalist as Programmer: A Case Study of The New York Times Interactive News Technology Department. ISOJ Journal, 2(1), 5-22.

Ryfe, D. M. (2012). Can journalism survive? An inside look at American newsrooms. Cambridge; Malden, MA: Polity Press.

Schmitz Weiss, A. \& Domingo, D. (2010). Innovation processes in online newsrooms as actor-networks and communities of practice. New Media \& Society, 12(7), 1156-1171. doi:10.1177/1461444809360400

Schumpeter, J. A. (1934/1997). The Theory of Economic Development. New Brunswick: Transaction USA.

Schweizer, T. S. (2003). Managing Interactions between Technological and Stylistic Innovation in the Media Industries. Technology Analysis \& Strategic Management, 15(1), 19-41.

Seelos, C. \& Mair, J. (2012). Innovation is not the Holy Grail. Stanford Social Innovation Review, Fall 2012, Downloaded 2014-06-26 from 
http://www.ssireview.org/pdf/Fall_2012_Innovation_Is_Not_the_Holy_Grail. pdf

Singer, J. B. (2014). User-generated visibility: Secondary gatekeeping in a shared media space. New Media \& Society, 16(1), 55-73. doi:

$10.1177 / 1461444813477833$

Smythe, D. W. (1977). Communications: Blindspot of Western Marxism. Canadian Journal of Political and Society Theory, 1(3), 1-28.

Snow C. C., Miles, R. E., \& Miles, G. (2005). A configurational approach to the integration of strategy and organization research. Strategic Organization, 3(4), 431-439. doi: 10.1177/1476127005057965

Stark, D. (2009). The sense of dissonance: Accounts of worth in economic life. Princeton, NJ: Princeton University Press.

Steensen, S. (2011). Online journalism and the promises of new technology: A critical review and look ahead. Journalism Studies, 12(3), 311-327. doi: 10.1080/1461670X.2010.501151

Stensson, P. \& Jansson, A. (2014). Autonomous technology - sources of confusion: a model for explanation and prediction of conceptual shifts. Ergonomics, 57(3), 455-470.

Storsul, T. \& Krumsvik, A. H. (2013). What is Media Innovation?, In T. Storsul \& A. H. Krumsvik (Eds.), Media Innovations. A Multidisciplinary Study of Change (pp. 13-26), Gothenburg: Nordicom.

Sylvie, G. (1996). Departmental Influences on Interdepartmental Cooperation at Daily Newspapers. Journalism \& Mass Communication Quarterly, 73(1), 230-241. doi: 10.1177/107769909607300120

Sylvie, G., \& Schmitz Weiss, A. (2012). Putting the Management into Innovation \& Media Management Studies: A Meta-Analysis. International Journal on Media Management, 14(3), 183-206. doi: 10.1080/14241277.2011.633584

Tidd, J. \& Bessant, J. (2013). Managing Innovation: Integrating technological, market and organizational change. Chichester: John Wiley \& Sons.

Turow, J. (2005). Audience construction and culture production: Marketing surveillance in the digital age. The ANNALS of the American Academy of Political and Social Science, 597(1), 103-121.

doi:10.1177/0002716204270469

Underwood, D. (1993). When MBAs Rule the Newsroom: How the Marketers and Managers are Reshaping Today's Media. New York: Columbia University Press.

Valanto, V., Kosonen, M. \& Ellonen, H.-K. (2012). Are publishers ready for tomorrow? Publishers' capabilities and online innovations. International Journal of Innovation Management, 16(1), 1-18.

van Dalen, A. (2012). The algorithms behind the headlines: How machine-written news redefines the core skills of human journalists. Journalism Practice, 6(56), 648-658. doi:10.1080/17512786.2012.667268. 
von Hippel, E. (1986). Lead Users: A Source of Novel Product Concepts. Management Science, 32(7), 791-805. doi: 10.1287/mnsc.32.7.791 von Hippel, E. (2005). Democratizing innovation. Cambridge, MA: MIT Press Wade, M., \& Hulland, J. (2004). Review: The Resource-Based View and Information Systems Research: Review, Extension, and Suggestions for Future Research. MIS Quarterly, 28 (1), 107-142.

Weick K. E., \& Quinn, R. E. (1999). Organizational Change and Development. Annual Review of Psychology, 50, 361-388. doi: 10.1146/annurev.psych.50.1.361

Westlund, O. (2011). Cross-media News Work: Sensemaking of the Mobile Media (R)evolution. Gothenburg: University of Gothenburg. https://gupea.ub.gu.se/bitstream/2077/28118/1/gupea_2077_28118_1.pdf Westlund, O. (2012). Producer-Centric Vs. Participation-Centric: On the Shaping of Mobile Media. Northern Lights, 10(1), 107-121. doi: 10.1386/nl.10.107_1 Westlund, O. (2013). Mobile news: A review and model of journalism in an age of mobile media. Digital Journalism, 1(1), 6-26. doi:10.1080/21670811.2012.74027

Wirth, M. O. (2006). Issues in media convergence, Handbook of media management and economics, In A. B. Albarran, S. Chan-Olmsted \& M. O. Wirth (Eds.), Handbook of media management and economics (pp. 445-462), Mahwah, NJ: Lawrence Erlbaum Associates, Inc.

Zelizer, B. (2004). Taking journalism seriously: News and the academy. New York: Sage.

Zollo, M. \& Winter, S. G. (2002). Deliberate learning and the evolution of dynamic capabilities. Organization Science, 13(3), 339-351. 